Berkala Ilmu Perpustakaan dan Informasi, Vol. 14, No. 1, Juni 2018 Hal. 62-75 DOI: $10.22146 /$ bip.33408

ISSN 1693-7740 (Print), ISSN 2477-0361 (Online)

Tersedia online di https://jurnal.ugm.ac.id/bip

\title{
Tingkat kolaborasi, produktivitas penulis dan artikel metrik pada Jurnal Mechatronics, Electrical Power, and Vehicular Technology
}

\author{
Noorika Retno Widuri' dan Abdurrakhman Prasetyadi ${ }^{1}$ \\ ${ }^{1}$ UPT Balai Informasi Teknologi LIPI \\ Email:noorika.rw@gmail.com
}

Naskah diterima: 22 Februari 2018, direvisi: 6 Maret 2018, disetujui: 24 April 2018

\begin{abstract}
ABSTRAK
Pendahuluan. Jurnal Mechatronics, Electrical power, and Vehicular technology merupakan jurnal ilmiah pada bidang tenaga listrik dan mekatronik. Berdasarkan observasi awal diketahui bahwa kajian bibliometrik di bidang tenaga listrik dan mekatronik belum pernah dilakukan. Kajian ini bertujuan untuk mengetahui tingkat kolaborasi penulis, tingkat produktivitas penulis, dan artikel metrik di jurnal MEV.

Metode penelitian. Metode yang digunakan yaitu deskriptif kualitatif dengan pendekatan bibliometrik. Data dikumpulkan dengan mencatat nama tiap penulis individu dan kolaborasi di jurnal MEV periode 2010-2016.

Data analisis. Analisis tingkat kolaborasi menggunakan rumus dari Subramanyam dan perhitungan frekuensi produktivitas penulis.

Hasil dan Pembahasan. Tingkat kolaborasi jurnal MEV yaitu 0,89, ini menunjukkan bahwa penulisan secara berkolaborasi di bidang tenaga listrik dan mekatronik cukup tinggi. Selanjutnya penulis paling produktif selama 20102016 yaitu Estiko Rijanto dengan 12 artikel. Sementara berdasarkan kelompok penelitian, penulis-penulis dari kelompok penelitian mekatronik yang paling produktif. Terakhir, artikel yang sering diunduh berjudul Hardware simulation of automatic braking system based on fuzzy logic control yang diterbitkan pada Vol. 7(1) tahun 2016. Hal ini menandakan kemungkinan tren penelitian saat itu yakni pada automatic braking devices/methods (klas 62-783.52). Kesimpulan dan Saran. Tingkat kolaborasi bidang tenaga listrik dan mekatronik di jurnal MEV cukup tinggi. Saran dari kajian ini perlu dilakukan penelitian lebih lanjut khususnya mengukur produktivitas penulis menggunakan dalil lotka.
\end{abstract}

Kata Kunci: Tingkat kolaborasi; Produktivitas penulis; Artikel metrik; Jurnal MEV

\section{ABSTRACT}

Introduction. Journal of Mechatronics, Electrical power, and Vehicular (MEV) technology is a scientific journal in the field of electric power and mechatronics. Based on the preliminary observation, limited bibliometric studies have been found in the field of electric power and mechatronics. This research was conducted to study the collaborative level of authors, productivity level of authors, and analyze metric article in Journal of MEV.

Data Collection Method. This research used qualitative descriptive method using bibliometric approach. Data were collected by recording the names of authors and their collaboration from 2010-2016.

Data Analysis. The collaborative level was analyzed by using Subramanyam formula to calculate the frequency of authors' productivity.

Results and Discussions. The results showed that collaborative level of Journal of MEV was 0.89. The results showed high tendency for authors to write in a collaborative group.. It was found that Estiko Rijanto became the most productive author with 12 articles. Based on research groups, authors from the mechatronics research group were found as the most productive. The probability of current research trend were found to have a relation to automatic braking devices/braking methods (klas 62-783.52).

Conclusions. Collaborative level in the field of electric power and mechatronics published in Journal of MEV was relatively high.

Keywords: Level of collaboration; Productivity of author; Article metric; MEV Journal 


\section{A. PENDAhuluan}

Kepengarangan ialah aspek yang sangat penting dalam penyebaran informasi dan kegiatan komunikasi ilmiah. Kontribusi kepengarangan dapat dilihat dari pola yang berbeda, seperti penulis tunggal, penulis bersama, dan beberapa penulis (Aliyu, 2011). Kepengarangan secara individu maupun berkolaborasi biasanya dipengaruhi oleh tingkat kesulitan suatu masalah pada penelitian, semakin tinggi tingkat kesulitan maka diperlukan penelitian secara berkolaborasi (Rufaidah, 2008).

Menurut Rufaidah (2008) juga untuk menanggulangi permasalahan penelitian diperlukan kerjasama dari berbagai latar bidang keahlian penulis. Melalui kerja sama, permasalahan dapat dipecahkan dan dapat menghasilkan penelitian yang baik. Anom (2012) mengatakan keterbatasan pengetahuan penulis individu dan sumber daya fisik lain dapat mendorong penelitian secara berkolaborasi.

Keuntungan penelitian secara kolaborasi salah satunya dapat meningkatkan produktivitas penulis. Menurut Wulan (2014), faktor utama yang membuat tingkat produktivitas penulis tinggi di jurnal Berita Biologi karena penulis tersebut memiliki frekuensi kolaborasi yang sering. Selain itu, penelitian secara berkolaborasi lebih banyak dimanfaatkan dari bidang ilmu IPA dan teknik. Pada penelitian sebelumnya, Prasetyadi \& Nugroho (2014) menunjukkan bahwa rata-rata kolaborasi kepengarangan dalam bidang teknik dan kebumian (geoteknologi) cukup tinggi karena melibatkan kepakaran multidisiplin.

Pada umumnya, karya tulis ilmiah (KTI) merupakan output dari kolaborasi penelitian dan dapat digunakan untuk mengukur tingkat kolaborasi penelitian. KTI yang dihasilkan dari suatu penelitian merupakan bagian penting dari proses penelitian sehingga KTI yang diterbitkan merupakan output terukur dari kolaborasi penelitian (Suryantini \& Nurdiana, 2016).

Haeffner-Cavaillon \& Claude (2009) mengungkapkan bahwa untuk mengukur sebuah kegiatan penelitian dapat dilakukan dengan kajian bibliometrik. Diodato (1994) mendefinisikan bibliometrik yaitu:

Bibliometrics is a field that uses mathematical and statistical techniques, from counting to calculus, to study publishing and communication patterns in the distribution of information".

Sementara itu, Sulistyo-Basuki (2002) memaknai bibliometrika sebagai kajian yang menerapkan rumus-rumus matematika dan statistika untuk mengukur suatu perubahan pada sekumpulan dokumen atau media lain baik kuantitatif maupun kualitatif. Metode ini memanfaatkan data bibliografis dari jurnal sebagai masukan indikator kolaborasi. Jadi bibliometrik bisa dimaknai kajian yang mengacu pada analisis secara matematis dan statistik terhadap pola-pola yang terjadi dalam publikasi dan penggunaan dokumen.

Jurnal Mechatronics, Electrical power, and Vehicular technology (MEV) merupakan majalah ilmiah internasional yang diterbitkan oleh Pusat Penelitian Tenaga Listrik dan Mekatronik LIPI. Jurnal MEV menerbitkan KTI yang berfokus pada mekatronik, tenaga listrik dan teknologi kendaraan. Jurnal MEV terbit secara konsisten selama 2 kali dalam satu tahun sejak tahun 2010. Pada tahun 2013, Jurnal MEV mulai menggunakan bahasa Inggris, memperoleh DOI (Digital Object Identifier) dan terindeks internasional. Berdasarkan observasi awal diketahui bahwa kajian bibliometrik mengenai bidang tenaga listrik dan mekatronik belum pernah dilakukan.

Tujuan dari pengkajian adalah 1) mengetahui tingkat kolaborasi penulis jurnal MEV, 2) mengetahui tingkat produktivitas penulis jurnal MEV, dan 3) menganalisis artikel metrik jurnal MEV. Kebaruan dari kajian ini adalah dilakukan analisis tingkat produktivitas penulis hingga kelompok penelitian (kelti) peneliti dan membahas artikel metrik jurnal MEV untuk mengetahui tren penelitian di bidang tenaga listrik dan mekatronik.

\section{B. TINJAUAN PUSTAKA Jurnal Ilmiah}

Majalah atau jurnal merupakan literatur primer yang sangat penting. Jurnal memiliki frekuensi terbit yang relatif cepat dan teratur, 
sehingga artikel-artikel yang dimuat lebih mutakhir. Jurnal ilmiah merupakan terbitan berkala yang diterbitkan oleh instansi pemerintah, akademik maupun organisasi profesi. Artikel-artikel di jurnal ilmiah merupakan produk pemikiran ilmiah secara empiris (artikel hasil penelitian) dan logis (artikel hasil pemikiran) dalam suatu bidang tertentu (Suryoputro, Riadi, \& Sya'ban, 2012). Sulistyo-Basuki menuturkan bahwa artikel ilmiah artinya artikel yang memperluas pengetahuan berdasarkan hasil penelitian. (Sulistyo-Basuki, 2004).

\section{Kolaborasi}

Kolaborasi dalam bahasa Inggris "collaboration" memiliki makna kerjasama. Sejarah kolaborasi muncul sejak lahirnya sebuah ilmu pengetahuan. Dalam publikasi penelitian, kolaborasi dapat meningkatkan popularitas suatu kegiatan dan dapat mempengaruhi proses dan hasil yang dicapai. Dalam konteks penelitian, kolaborasi penulisan diperlukan, mengingat tidak selamanya penelitian dilakukan secara individu. Karena hal tersebut, maka dibutuhkan kerjasama antar peneliti maupun antar instansi baik dalam hal gagasan atau ide, pendanaan, sarana dan peralatan.

Sutarsyah (2014) menjelaskan beberapa keuntungan yang diperoleh penulis bila berkolaborasi, yakni memungkinkan adanya kesempatan berbagi pengetahuan, keahlian, dan teknik-teknik tertentu dalam sebuah ilmu. Keuntungan lainnya adalah membantu memecahkan permasalahan yang kompleks, sehingga menghasilkan KTI dengan kualitas yang lebih baik.

Bukvova (2010) mengemukakan alasanalasan untuk berkolaborasi, yaitu: akses untuk keahlian; akses untuk sumber daya; berbagi ide (sharing knowledge) antar disiplin ilmu; sebagai media berkumpulnya para pakar dalam memecahkan masalah yang kompleks; lebih fokus pada aktivitas penelitian; mempelajari keterampilan baru; meningkatkan produktivitas; meningkatkan kualitas; akses pendanaan; gengsi peneliti dan institusi; aspek politik; alasan personal; dan hiburan dan kesenangan (Handoyo \& Putera, 2012).

Penulis berpendapat bahwa kolaborasi bisa terjadi lebih dari satu lembaga. Pada beberapa kegiatan penelitian, peneliti bekerja sama dengan berbagai instansi pemerintah dengan akademik dan/atau antar instansi pemerintah. Misalnya LIPI bekerja sama dengan BPPT dan ITB sekaligus, atau bahkan bekerja sama dengan swasta dan organisasi sosial maupun kemasyarakatan lainnya.

\section{Produktivitas Penulis}

Menurut Lotka (1926) produktivitas penulis adalah banyaknya karya tulis yang dihasilkan oleh seseorang secara individual maupun secara kolaborasi dalam subjek tertentu dan diterbitkan pada jurnal-jurnal ilmiah baik dalam skala nasional maupun internasional dalam subjek tertentu dan dalam kurun waktu tertentu. Produktivitas penulis disebut juga produktivitas ilmiah, produktivitas ilmiah menunjukkan jumlah publikasi ilmiah baik yang terindeks maupun tidak terindeks secara nasional dan internasional.

Mengukur produktivitas penulis menurut Dewiyana \& Arianti (2009) berfungsi untuk mengetahui penulis-penulis produktif dan yang paling produktif dalam jurnal ilmiah dan kurun waktu tertentu. Hal yang sama juga disampaikan oleh Diodata (1994), mendefinisikan bahwa produktivitas ilmiah sebagai jumlah penelitian yang dihasilkan ilmuwan. Produktivitas ilmiah di berbagai bidang ilmu dapat diukur melalui berbagai data seperti jumlah publikasi yang dihasilkan oleh penulis dan jumlah kutipan dari publikasi penulis tersebut (Tupan, 2017).

\section{METODE PENELITIAN}

Metode yang digunakan adalah deskriptif kualitatif dengan analisis bibliometrik. Data yang digunakan dari kajian ini berasal dari artikel jurnal MEV yang dipublikasikan online mulai Vol.1 tahun 2010 s.d. Vol.7 tahun 2016. Data dikumpulkan dengan mencatat nama tiap penulis individu dan kolaborasi, kemudian diolah di perangkat lunak spreadsheet. Tujuannya untuk memudahkan pendistribusian 
data dan tampilan dalam format grafik. Selanjutnya data dikelompokkan berdasarkan:

- Jumlah artikel dan penulis

- Tingkat Kolaborasi penulisan selama 2010 2016

- Penyebaran penulis produktif selama 2010 2016

- Sebaran institusi

- Peringkat artikel metrik

Analisis yang pertama dilakukan adalah menentukan tingkat kolaborasi penulis di jurnal MEV menggunakan rumus dari Subramanyam (1983):

$$
\mathrm{C}=\frac{N_{\mathrm{m}}}{N_{\mathrm{m}}+N_{\mathrm{s}}}
$$

di mana:

$\mathrm{C}=$ Tingkat kolaborasi peneliti suatu disiplin ilmu, dengan nilai berada pada interval 0 sampai dengan 1 , atau $[0,1]$

$N_{\mathrm{m}}=$ Total hasil penelitian dari peneliti suatu disiplin ilmu pada tahun tertentu yang dilakukan secara berkolaborasi.

$N_{\mathrm{s}}=$ Total hasil penelitian dari peneliti suatu disiplin ilmu pada tahun tertentu yang dilakukan secara individual.

- Apabila nilai $\mathrm{C}=0$ maka dapat dikatakan bahwa hasil penelitian pada bidang tersebut seluruhnya dilakukan secara individual (peneliti tunggal).

- Apabila nilai C lebih besar dari nol dan kurang dari setengah $(0<\mathrm{C}<0,5)$ maka dapat dikatakan bahwa hasil penelitian yang dilakukan secara individual lebih besar dibandingkan dengan yang dilakukan secara berkolaborasi.

- Apabila nilai $\mathrm{C}=0,5$ maka penelitian yang dilakukan secara individual sama banyaknya dengan yang dilakukan secara berkolaborasi.

- Apabila nilai $\mathrm{C}$ lebih besar dari 0,5 dan kurang dari $1(0,5<\mathrm{C}<1)$ dapat dikatakan bahwa hasil penelitian yang dilakukan secara individual lebih sedikit dibandingkan yang dilakukan secara berkolaborasi.

- Apabila nilai $\mathrm{C}=1$ maka penelitian pada bidang tersebut seluruhnya dilakukan secara berkolaborasi (Sormin, 2009).

Kedua, untuk menganalisis produktivitas penulis di jurnal MEV menggunakan rumus:

$\mathrm{P}=\frac{F}{N} \times 100 \%$

$\mathrm{P}=$ Persentase

$\mathrm{F}=$ Frekuensi jumlah artikel/kepengarangan/ distribusi/jenis kelamin/kelompok penelitian/bahasa/instansi

$\mathrm{N}=$ Jumlah total artikel/kepengarangan/ distribusi/jenis kelamin/kelompok penelitian/bahasa/instansi

Hasil perhitungannya dapat dianalisis dalam bentuk tabel agar bisa ditarik suatu kesimpulan (Rahayu \& Rachmawati, 2015).

\section{HASIL DAN PEMBAHASAN Tingkat Kolaborasi Penulis}

Selama tahun 2010-2016, jurnal MEV memuat 99 tulisan baik kolaborasi maupun individu, dengan total jumlah penulis 208 penulis. Secara rinci, distribusi artikel setiap tahun dapat dillihat pada Tabel 1.

Dalam periode satu tahun, jurnal MEV konsisten menerbitkan 2 nomor dalam satu volume. Tabel 1 memperlihatkan adanya perbedaan jumlah artikel yang dimuat dalam jurnal MEV setiap tahunnya. Pada tahun 2014, tercatat 17 artikel yang dipublikasikan, dan terendah di tahun 2010 hanya 10 artikel.

Berdasarkan hasil perhitungan ditemukan bahwa dari 99 artikel, 74\% berbahasa Inggris dan hanya $26 \%$ berbahasa Indonesia. Sejak terbit tahun 2010, bahasa yang digunakan masih didominasi bahasa Indonesia, namun sejak Vol. 4 tahun 2012, bahasa yang digunakan beralih menjadi bahasa Inggris. Sementara itu, kondisi kepengarangan dalam Jurnal MEV dapat dilihat pada Tabel 2 .

Tabel 2 menunjukkan kepengarangan artikel yang dipublikasikan selama periode 2010-2016. Jumlah minimal artikel ditulis oleh 
satu orang dan jumlah maksimal di tulis oleh 9 orang. Jumlah terbanyak ditulis oleh 3 penulis $(41,41 \%)$ dan paling sedikit ditulis oleh 5 penulis $(6,06 \%)$. Pada Tabel 2 juga menunjukkan bahwa dari 99 artikel tersebut hanya sebanyak $10,10 \%$ yang ditulis secara perseorangan, 89,90\% lainnya ditulis secara gabungan atau kolaborasi.

Pada Tabel 3 menunjukkan data kepengarangan secara perorangan dan kolaborasi sejak tahun 2010-2016. Kepengarangan didominasi secara berkolaborasi dengan jumlah pengarang kolaborasi 89 artikel $(89,90 \%)$. Lebih lengkapnya dapat dilihat pada Tabel 3 .

Untuk menentukan derajat kolaborasi digunakan rumus Subramanyam (1983) sebagai berikut:

$$
\mathrm{C}=\frac{N_{\mathrm{m}}}{N_{\mathrm{m}}+N_{\mathrm{s}}}
$$

Sehingga dapat ditentukan bahwa:

$$
\mathrm{C}=\frac{89}{89+10}=0,89
$$

Hasil perhitungan derajat kolaborasi di jurnal MEV adalah 0,89, ini berarti nilai $\mathrm{C}$ lebih besar dari 0,5 dan kurang dari $1(0,5<\mathrm{C}<1)$ dapat dikatakan bahwa hasil penelitian yang dilakukan secara berkolaborasi lebih banyak ketimbang individu.

\section{Produktivitas Penulis}

Pada Tabel 4 memperlihatkan distribusi pengarang dan artikel di jurnal MEV dalam periode 2010-2016. Penulis terbanyak terdapat pada tahun 2015 yaitu sebanyak 58 penulis atau $18,41 \%$ dan penulis paling sedikit ada pada tahun 2010 yakni 32 penulis atau $10,15 \%$. Jurnal MEV belum memiliki konsistensi dalam memuat jumlah artikelnya per tahun. Artikel terbanyak ada di tahun 2014, sementara artikel paling sedikit ada di tahun 2010 hanya 10 artikel $(10,15 \%)$. Lebih lengkap dapat dilihat pada Tabel 4.
Pada Tabel 5 diketahui bahwa Estiko Rijanto merupakan penulis paling produktif dari 206 orang penulis selama 2010 - 2016. Nama Estiko muncul di 12 judul artikel yang seluruhnya berkolaborasi, baik sebagai penulis pertama, kedua maupun ketiga. Selanjutnya yakni Hendri Maja Saputra sebanyak 8 judul artikel, dan Midriem Mirdanies sebanyak 7 artikel. Midriem Mirdanies, sebanyak tiga kali sebagai penulis pertama. Pudji Irasari, 6 artikel. Aditya Sukma Nugraha, Arifin Nur dan Hilman Syaeful Alam masing-masing 5 artikel. Kristian Ismail, Ridwan Arief Subekti, Roni Permana, Yanuandri dan Zainal Abidin masing-masing 4 artikel.

Selanjutnya pada Tabel 6 menggambarkan daftar peringkat 1-12 dari 206 penulis yang paling produktif dalam penulisan karya ilmiah secara rinci mulai tahun 2010 s.d. 2016.

Pusat Penelitian Tenaga Listrik dan Mekatronik (P2 Telimek) LIPI sebagai penerbit jurnal MEV, dalam melaksanakan tugasnya dibagi menjadi empat kelompok penelitian (kelti) yakni: (1) kelti konversi dan konservasi energi; (2) kelti elektronika daya dan mesin listrik; (3) kelti alat transportasi; dan (4) kelti mekatronik. Berikut adalah produktifitas penulis di jurnal MEV berdasarkan kelti tersebut.

Pada Gambar 2 menjelaskan bahwa yang paling banyak berkontribusi pada jurnal MEV adalah penulis dari kelti mekatronik. Bahkan pada kelti tersebut, terdapat empat pengarang yang paling produktif yakni Estiko Rijanto, Hendri Maja, Midriem dan Aditya Sukma. Apabila dirinci berdasarkan masing-masing kelti, kelti pertama yakni kelti konversi dan konversi energi penulis paling produktifnya yaitu Ghalya Pikra. Berikutnya ada Kristian Ismail dan Yanuandri Putrasari yang masingmasing berkontribusi pada 2 artikel, lebih lengkapnya dapat dilihat pada Tabel 7.

Kedua, kelti elektronika daya dan mesin listrik penulis paling produktifnya yaitu Pudji Irasari dengan 6 artikel. Selanjutnya ada Ridwan Arif Subekti dan Anwar Muqorobim, lebih lengkap pada Tabel 8.

Ketiga, kelti alat transportasi penulis paling produktifnya yakni Arifin Nur dengan 5 artikel. 
Selanjutnya ada Kristian Ismail dan Yanuandri Putrasari, lebih lengkap pada Tabel 9.

Terakhir, kelti mekatronik penulis paling produktifnya yakni Estiko Rijanto dengan 12 artikel. Selanjutnya ada Kristian Ismail dan Yanuandri Putrasari, lebih lengkap pada Tabel 10.

Pada Grafik 1 menjelaskan asal instansi tiap pengarang yang menulis artikel di jurnal MEV. Asal instansi didominasi dari P2 Telimek LIPI dengan 46 pengarang, kemudian diikuti oleh ITB dengan 15 pengarang.

\section{Artikel Metrik}

Artikel metrik merupakan jumlah artikel yang dilihat dan diunduh dalam format Pdf. Pada situs Online Journal System (OJS) MEV sudah dihitung secara otomatis masing-masing artikel yang dilihat dan diunduh setiap bulan. Pada kajian ini diperoleh hasil analisis artikel metrik jurnal MEV dari tahun 2010-2016, lihat pada Tabel 11.

Pada Tabel 11 menjelaskan artikel-artikel pada tahun 2016 (4 artikel) yang paling banyak dilihat dan diunduh. Artikel dengan unduhan terbanyak yaitu berjudul Hardware simulation of automatic braking system based on fuzzy logic control yang diterbitkan pada Vol. 7(1) tahun 2016. Kemudian artikel tersebut ditentukan nomor klasifikasinya menggunakan peraturan UDC (Universal Decimal Classification). Ternyata nomor klas 62-783.52 (automatic braking devices/braking methods) adalah klas paling banyak dicari. Hal ini menandakan kemungkinan tren penelitian saat itu yakni pada automatic braking devices/braking methods.

\section{E. KESIMPULAN}

Kajian ini telah memperoleh tingkat kolaborasi penulis bidang tenaga listrik dan mekatronik di jurnal MEV. Tingkat kolaborasi tersebut yaitu 0,89 . Hal ini menunjukkan bahwa penulisan secara berkolaborasi di bidang tenaga listrik dan mekatronik lebih banyak dilakukan daripada secara individu.

Hasil kajian juga menunjukkan penulispenulis yang produktif dan paling produktif. Penulis paling produktif dari 206 penulis selama periode 2010 s.d. 2016 yaitu Estiko Rijanto dengan 12 artikel. Sementara berdasarkan kelti yang ada di P2 Telimek LIPI, penulis-penulis dari kelti mekatronik yang paling produktif di jurnal MEV.

Terakhir, hasil analisis artikel metrik mengenai artikel yang sering dilihat dan diunduh terdapat pada tahun 2016 (4 artikel). Artikel dengan unduhan terbanyak berjudul Hardware simulation of automatic braking system based on fuzzy logic control yang diterbitkan pada Vol. 7(1) tahun 2016. Hal ini menandakan kemungkinan tren penelitian saat itu yakni pada automatic braking devices/braking methods (klas 62-783.52).

\section{UCAPAN TERIMA KASIH}

Kami ucapkan terima kasih kepada sivitas P2 Telimek LIPI, khususnya Ibu Ghalya Pikra, salah satu redaksi jurnal MEV, Ibu Emil Kristanti dan Nurul Fadjriah bagian kepegawaian yang berkenan mengirimkan datadata terkait kelti dan kepakaran peneliti di P2 Telimek LIPI. Serta kepada Sri, Shofa dan Evita, siswa prakerin SMK Nasional Bandung yang membantu dalam mengolah data di aplikasi spreadsheet.

\section{DAFTAR PUSTAKA}

Aliyu, M. (2011). Author productivity and colaboration among academic scientists in Modibbo Adama University of Technology, Yola. The Information Manage, 11(1\&2), 32-35.

Anom, S. (2012). Kolaborasi peneliti bidang sains: Sebuah kajian bibliometrik pada makara seri sains dan jurnal matematika dan sains. Depok: Universitas Indonesia.

Bukvova, H. (2010). Studying research collaboration: A literature review. Sprouts: Working Papers on Information Systems, 10(3). Retrieved April 24, 2018 from https://pdfs.semanticscholar.org/1126/d981 037d4a640ac92b3b7e81fe4111f26a6a.pdf

Dewiyana, H., \& Arianti, F. (2009). Produktivitas pengarang pada jurnal program studi di lingkungan Universitas Sumatera Utara (USU) terbitan USU Press Tahun 2004-2006. Medan: USU Press. 
Diodato, V. P. (1994). Dictionary of Bibliometrics. Binghamton, New York: Haworth Press.

Haeffner-Cavaillon, N., \& Claude. (2009). The use of bibliometric indicators to help peerreview assessment. Archivum Immunologiae et Therapiae Experimentalis, 57(1), 33-38.

Handoyo, S., \& Putera, P. B. (2012). Tingkat kolaborasi peneliti pada program insentif "semi top-down" Kementerian Riset dan Teknologi, Tahun 2008 - 2010. Warta Kiml, 10(2), 99-114.

Lotka, A.J. (1926). The frequency distribution of scientific productivity. Journal of the Washington Academy of Sciences, 16(2), 317-323.

Prasetyadi, A., \& Nugroho, D. (2014). Kolaborasi kepakaran peneliti pada jurnal ilmiah LIPI bidang informatika dan kebumian. Visi Pustaka, 16(1), 5-13.

Rahayu, R. N., \& Rachmawati, R. (2015). Kolaborasi dan produktivitas penulis artikel Visi Pustaka 2000-2014. Baca: Jurnal Dokumentasi dan Informasi, 36(2), 141152.

Rufaidah, V. W. (2008). Kolaborasi dan graf komunikasi artikel ilmiah peneliti bidang pertanian: Studi kasus pada jurnal penelitian dan pengembangan pertanian. Jurnal Perpustakaan Pertanian, 17(1), 10-21.
Sormin, R. (2009). Kajian korelasi antara kolaborasi peneliti dan produktivitas peneliti lingkup badan litbang pertanian. Jurnal Perpustakaan Pertanian, 18(1), 1-6.

Subramanyam. K. (1983). Bibliometric studies of research collaboration. Journal of Information Science, 6, 33-38.

Sulistyo-Basuki. (2002). Bibliometrika, sainsmetrika, dan infometrika. Kumpulan makalah kursus bibliometrika. Jakarta: Masyarakat Infometrika Indonesia.

Suryantini, H., \& Nurdiana. (2016). Kolaborasi peneliti bidang bioteknologi dan sumber daya genetik pertanian pada jurnal Agrobiogen. Jurnal Perpustakaan Pertanian, 25(2), 63-70.

Suryoputro, G., Riadi, S., \& Sya'ban, A. (2012). Menulis artikel untuk jurnal Ilmiah. Jakarta: UHAMKA Press.

Sutarsyah. (2014). Kajian profil artikel dan produktivitas penulis pada Warta Kebun Raya. Visi Pustaka, 16(3), 230-234.

Tupan. (2017). Knowledge sharing pustakawan UPT Balai Informasi Teknologi LIPI. Bandung: BIT LIPI.

Wulan, S. (2014). Produktivitas dan tingkat kolaborasi penulis dalam karya tulis ilmiah peneliti bidang Zoologi, Puslit Biologi-LIPI 2005-2010. Visi Pustaka, 16(2), 176-184. 


\section{DAFTAR GAMBAR}

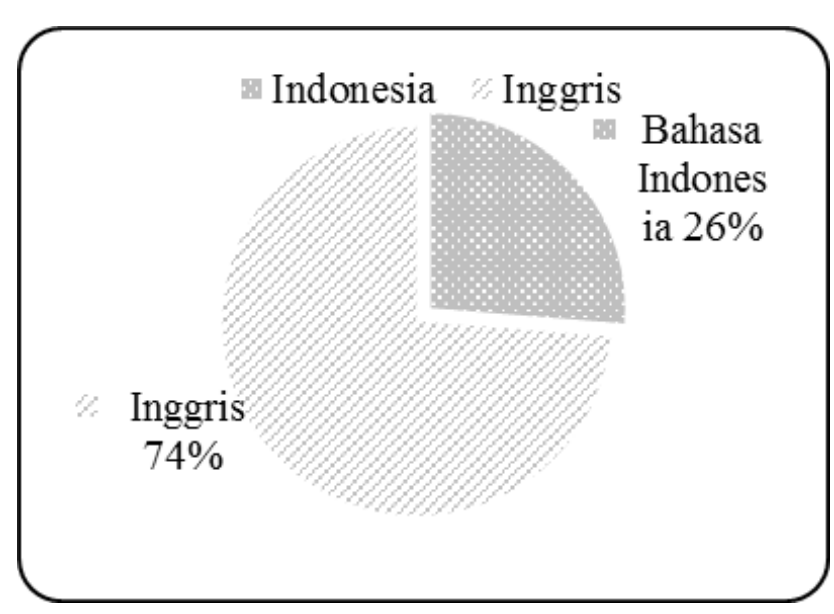

Gambar 1. Komposisi bahasa

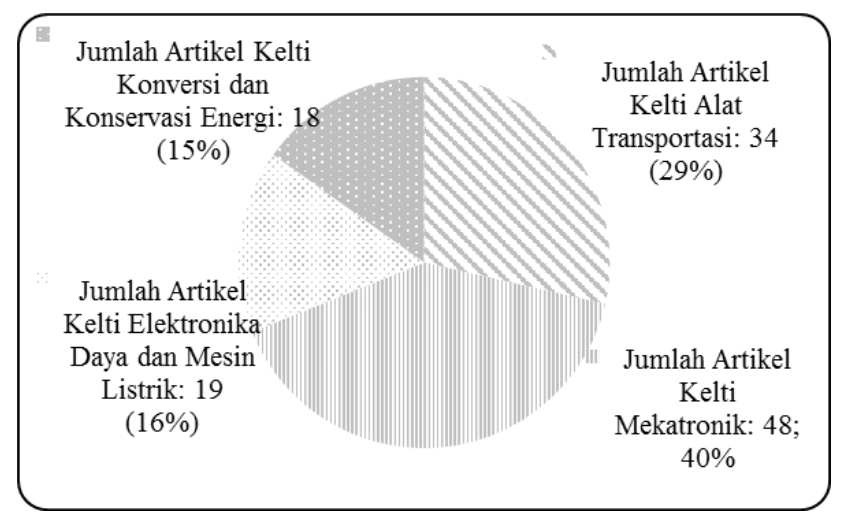

Gambar 2. Produktivitas penulis berdasarkan kelti 


\section{DAFTAR TABEL}

Tabel 1. Distribusi Artikel Setiap Tahun

\begin{tabular}{clccc}
\hline Tahun & Volume/Nomer & $\begin{array}{c}\text { Jumlah } \\
\text { Terbitan }\end{array}$ & $\begin{array}{c}\text { Jumlah } \\
\text { Artikel }\end{array}$ & \% artikel \\
\hline 2010 & Vol. 1 (1);(2) & 2 & 10 & $10.10 \%$ \\
2011 & Vol. 2 (1);(2) & 2 & 13 & $13.13 \%$ \\
2012 & Vol. 3 (1);(2) & 2 & 15 & $15.15 \%$ \\
2013 & Vol. 4 (1);(2) & 2 & 16 & $16.16 \%$ \\
2014 & Vol. 5 (1);(2) & 2 & 17 & $17.17 \%$ \\
2015 & Vol. 6 (1);(2) & 2 & 15 & $15.15 \%$ \\
2016 & Vol. 7 (1);(2) & 2 & 13 & $13.13 \%$ \\
& Total & 14 & 99 & $100.00 \%$ \\
\hline
\end{tabular}

Tabel 2. Kepengarangan pada Jurnal MEV

\begin{tabular}{cccccccccc}
\hline Jumlah & \multicolumn{10}{c}{ Jurnal MEV } & & Jumlah & \% \\
Pengarang & $\mathbf{2 0 1 0}$ & $\mathbf{2 0 1 1}$ & $\mathbf{2 0 1 2}$ & $\mathbf{2 0 1 3}$ & $\mathbf{2 0 1 4}$ & $\mathbf{2 0 1 5}$ & $\mathbf{2 0 1 6}$ & & \\
\hline 1 pengarang & 1 & 4 & 0 & 1 & 2 & 0 & 2 & 10 & $10.10 \%$ \\
2 Pengarang & 3 & 1 & 5 & 4 & 4 & 1 & 2 & 20 & $20.20 \%$ \\
3 pengarang & 2 & 3 & 9 & 8 & 8 & 7 & 4 & 41 & $41.41 \%$ \\
4 pengarang & 2 & 3 & 1 & 1 & 2 & 4 & 1 & 14 & $14.14 \%$ \\
5 pengarang & 1 & 1 & 0 & 1 & 0 & 1 & 2 & 6 & $6.06 \%$ \\
$>$ 5 pengarang & 1 & 1 & 0 & 1 & 1 & 2 & 2 & 8 & $8.08 \%$ \\
Total & 10 & 13 & 15 & 16 & 17 & 15 & 13 & 99 & $100.00 \%$ \\
\hline
\end{tabular}

Tabel 3. Kepengarangan Perorangan dan Kolaborasi

\begin{tabular}{|c|c|c|c|c|c|c|c|c|c|}
\hline \multirow{2}{*}{ Jumlah Pengarang } & \multicolumn{7}{|c|}{ Jurnal MEV } & \multirow{2}{*}{ Jumlah } & \multirow{2}{*}{$\%$} \\
\hline & 2010 & 2011 & 2012 & 2013 & 2014 & 2015 & 2016 & & \\
\hline $\begin{array}{l}\text { Pengarang } \\
\text { perorangan }\end{array}$ & 1 & 4 & 0 & 1 & 2 & 0 & 2 & 10 & $10.10 \%$ \\
\hline $\begin{array}{l}\text { Pengarang } \\
\text { kolaborasi }\end{array}$ & 9 & 9 & 15 & 15 & 15 & 15 & 11 & 89 & $89.90 \%$ \\
\hline Total & 10 & 13 & 15 & 16 & 17 & 15 & 13 & 99 & $100.00 \%$ \\
\hline
\end{tabular}

Tabel 4. Distribusi Pengarang dan Artikel

\begin{tabular}{|c|c|c|c|c|c|c|c|c|c|}
\hline No. & Nama & 2010 & 2011 & 2012 & 2013 & 2014 & 2015 & 2016 & Total \\
\hline 1 & Pengarang & 32 & 44 & 41 & 48 & 48 & 58 & 44 & 315 \\
\hline \multirow[t]{3}{*}{2} & Artikel & 10 & 13 & 15 & 16 & 17 & 15 & 13 & 99 \\
\hline & $\%$ Pengarang & 10.1587 & 13.97 & 13.02 & 15.24 & 15.24 & 18.41 & 13.97 & 100 \\
\hline & $\%$ Artikel & 10.101 & 13.13 & 15.15 & 16.16 & 17.17 & 15.15 & 13.13 & 100 \\
\hline
\end{tabular}


Tabel 5. Kontribusi Pengarang

\begin{tabular}{ccc}
\hline No. & Penulis & $\begin{array}{c}\text { Jumlah } \\
\text { Artikel }\end{array}$ \\
\hline 1 & Estiko Rijanto & 12 \\
2 & Hendri Maja Saputra & 8 \\
3 & Midriem Mirdanies & 7 \\
4 & Pudji Irasari & 6 \\
5 & Aditya Sukma Nugraha & 5 \\
6 & Arifin Nur & 5 \\
7 & Hilman Syaeful Alam & 5 \\
8 & Kristian Ismail & 4 \\
9 & Ridwan Arief Subekti & 4 \\
10 & Roni Permana Saputra & 4 \\
& Yanuandri & 4 \\
11 & Putrasari & 4 \\
13 & Zainal Abidin & 3 \\
25 & 12 Pengarang lainnya & 2 \\
\hline
\end{tabular}

Tabel 6. Penulis jurnal MEV yang paling produktif selama periode 2010-2016

\begin{tabular}{|c|c|c|c|c|c|c|c|c|c|c|}
\hline No. & Penulis & ' 10 & $' 11$ & '12 & '13 & ‘ 14 & ' 15 & ' 16 & Jumlah & $\begin{array}{c}\text { Peringkat } \\
\text { Produktifit- } \\
\text { as }\end{array}$ \\
\hline 1 & Estiko Rijanto & 2 & 2 & 2 & 2 & 1 & 2 & 1 & 12 & 1 \\
\hline 2 & Hendri Maja Saputra & 1 & 2 & 1 & 2 & - & 1 & 1 & 8 & 2 \\
\hline 3 & Midriem Mirdanies & - & 2 & - & 2 & - & 1 & 2 & 7 & 3 \\
\hline 4 & Pudji Irasari & 1 & 1 & 2 & - & 2 & - & - & 6 & 4 \\
\hline 5 & Aditya Sukma Nugraha & 2 & 2 & - & - & 1 & - & - & 5 & 5 \\
\hline 6 & Arifin Nur & - & - & 1 & 1 & 2 & - & 1 & 5 & 5 \\
\hline 7 & Hilman Syaeful Alam & - & - & 2 & 1 & 1 & 1 & - & 5 & 5 \\
\hline 8 & Kristian Ismail & - & - & 1 & - & 1 & 2 & - & 4 & 6 \\
\hline 9 & Ridwan Arief Subekti & 2 & 1 & 1 & - & - & - & - & 4 & 6 \\
\hline 10 & Roni Permana Saputra & - & 2 & - & - & 1 & - & 1 & 4 & 6 \\
\hline 11 & Yanuandri Putrasari & 1 & - & 1 & 1 & 1 & - & - & 4 & 6 \\
\hline 12 & Zainal Abidin & 1 & - & 2 & 1 & - & - & - & 4 & 6 \\
\hline
\end{tabular}


Tabel 7. Produktifitas pengarang kelti konversi dan konversi energi di jurnal MEV

\begin{tabular}{|c|c|c|c|c|}
\hline No. & Nama & $\begin{array}{l}\text { Jumlah } \\
\text { Artikel }\end{array}$ & Kepakaran & $\begin{array}{c}\text { Produktifitas } \\
\text { Pengarang }\end{array}$ \\
\hline 1 & Ghalya Pikra, M.T. & 3 & $\begin{array}{c}\text { Konversi Energi } \\
(15.02)\end{array}$ & 1 \\
\hline 2 & Maulana Arifin, S.T. & 3 & $\begin{array}{c}\text { Konversi Energi } \\
\qquad(15.02)\end{array}$ & 1 \\
\hline 3 & Edy Riyanto, S.T. & 2 & $\begin{array}{c}\text { Teknik Material } \\
\text { (19.03) }\end{array}$ & 2 \\
\hline 4 & Andri Joko Purwanto, S.T. & 2 & $\begin{array}{c}\text { Konversi Energi } \\
\qquad(15.02)\end{array}$ & 2 \\
\hline 5 & Ir. Agus Salim & 2 & $\begin{array}{l}\text { Fungsional } \\
\text { Perekayasa }\end{array}$ & 2 \\
\hline 6 & Ir. Adi Santoso & 2 & $\begin{array}{c}\text { Telah } \\
\text { Pensiun }\end{array}$ & 2 \\
\hline 7 & Ir. Imam Djunaedi & 1 & $\begin{array}{c}\text { Perancangan Mesin } \\
(15.01)\end{array}$ & 3 \\
\hline 8 & Dalmasius Ganjar Subagio, S.T. & 1 & $\begin{array}{l}\text { Teknik Produksi } \\
\text { Mesin (15.03) }\end{array}$ & 3 \\
\hline 9 & Arini Wresta, M.Eng & 1 & $\begin{array}{c}\text { Teknologi } \\
\text { Bioenergi }(20.06)\end{array}$ & 3 \\
\hline 10 & Arifin Santosa, S.T. & 1 & $\begin{array}{c}\text { Konversi Energi } \\
(15.02)\end{array}$ & 3 \\
\hline
\end{tabular}

Tabel 8. Produktifitas pengarang di kelti elektronika daya dan mesin listrik di jurnal MEV

\begin{tabular}{|c|c|c|c|c|}
\hline No. & Nama & $\begin{array}{l}\text { Jumlah } \\
\text { Artikel }\end{array}$ & Kepakaran & $\begin{array}{c}\text { Produktifitas } \\
\text { Pengarang }\end{array}$ \\
\hline 1 & Pudji Irasari, M.Sc.rer.nat & 6 & $\begin{array}{c}\text { Tenaga Listrik } \\
(16.01)\end{array}$ & 1 \\
\hline 2 & Ridwan Arief Subekti, S.T. & 4 & $\begin{array}{l}\text { Konversi Energi } \\
(15.02)\end{array}$ & 2 \\
\hline 3 & Anwar Muqorobin, M.T. & 3 & $\begin{array}{c}\text { Tenaga Listrik } \\
(16.01)\end{array}$ & 3 \\
\hline 4 & Agus Risdiyanto, M.T. & 2 & $\begin{array}{l}\text { Tenaga Listrik } \\
(16.01)\end{array}$ & 4 \\
\hline 5 & Noviadi Arief Rachman, M.T. & 2 & $\begin{array}{l}\text { Tenaga Listrik } \\
\text { (16.01) }\end{array}$ & 4 \\
\hline 6 & Muhammad Kasim, S.T. MRerEn & 2 & $\begin{array}{c}\text { Tenaga Listrik } \\
(16.01)\end{array}$ & 4 \\
\hline
\end{tabular}


Tabel 9. Produktifitas pengarang di kelti alat transportasi di jurnal MEV

\begin{tabular}{|c|c|c|c|c|}
\hline No & Nama & $\begin{array}{l}\text { Jumlah } \\
\text { Artikel } \\
\end{array}$ & Kepakaran & $\begin{array}{c}\text { Produktifitas } \\
\text { Pengarang }\end{array}$ \\
\hline 1 & Arifin Nur, M.T. & 5 & $\begin{array}{c}\text { Konversi Energi } \\
(15.02)\end{array}$ & 1 \\
\hline 2 & Kristian Ismail, S.T. MT. & 4 & $\begin{array}{c}\text { Elektronika } \\
(16.02)\end{array}$ & 2 \\
\hline 3 & Yanuandri Putrasari, M.Eng & 4 & $\begin{array}{c}\text { Konversi Energi } \\
(15.02)\end{array}$ & 2 \\
\hline 4 & Ir. Abdul Hapid & 3 & $\begin{array}{c}\text { Teknik Otomotif } \\
(15.06)\end{array}$ & 3 \\
\hline 5 & Aam Muharam, S.T. M.T. & 3 & $\begin{array}{c}\text { Elektronika } \\
(16.02)\end{array}$ & 3 \\
\hline 6 & Bambang Wahono, M.Eng & 3 & $\begin{array}{c}\text { Konversi Energi } \\
(15.02)\end{array}$ & 3 \\
\hline 7 & Naili Huda, M.Eng.Sc & 3 & $\begin{array}{c}\text { Manajemen } \\
\text { Rantai Pasok dan } \\
\text { Logistik }(26.03)\end{array}$ & 3 \\
\hline 8 & Achmad Praptijanto, S.T. M.D.M & 2 & $\begin{array}{c}\text { Konversi Energi } \\
(15.02)\end{array}$ & 4 \\
\hline 9 & Sunarto Kaleg, S.T. & 2 & $\begin{array}{c}\text { Teknik Otomotif } \\
(15.06)\end{array}$ & 4 \\
\hline 10 & Ir. Widodo Budi Santoso, M.T. & 1 & $\begin{array}{l}\text { Konversi Energi } \\
\quad(15.02)\end{array}$ & 5 \\
\hline 11 & Amin, M.T & 1 & $\begin{array}{c}\text { Elektronika } \\
(16.02)\end{array}$ & 5 \\
\hline 12 & Muhammad Redho Kurnia, S.Sn & 1 & $\begin{array}{l}\text { Desain Produk } \\
\quad(41.09)\end{array}$ & 5 \\
\hline 13 & Kadek Heri Sanjaya, S.T. & 1 & $\begin{array}{l}\text { Biomekanika } \\
\quad(15.05)\end{array}$ & 5 \\
\hline 14 & Suherman, S.T. & 1 & $\begin{array}{c}\text { Perancangan } \\
\text { Mesin (15.01) }\end{array}$ & 5 \\
\hline
\end{tabular}

Tabel 10. Produktifitas pengarang kelti mekatronik di jurnal MEV

\begin{tabular}{|c|c|c|c|c|}
\hline No. & Nama & $\begin{array}{l}\text { Jumlah } \\
\text { Artikel }\end{array}$ & Kepakaran & $\begin{array}{c}\text { Produktifitas } \\
\text { Pengarang }\end{array}$ \\
\hline 1 & Prof. Dr. Estiko Rijanto & 12 & $\begin{array}{c}\text { Perancangan Mesin } \\
\text { (15.01), Sistem } \\
\text { Kontrol Terapan } \\
(15.01 .01)\end{array}$ & 1 \\
\hline 2 & Hendri Maja Saputra, M.T. & 8 & $\begin{array}{l}\text { Teknik Produksi } \\
\text { Mesin (15.03) }\end{array}$ & 2 \\
\hline 3 & Midriem Mirdanies, M.T. & 7 & $\begin{array}{l}\text { Teknik Sistem } \\
\text { Informasi (14.04) }\end{array}$ & 3 \\
\hline 4 & Aditya Sukma Nugraha, M.T. & 5 & $\begin{array}{c}\text { Perancangan Mesin } \\
(15.01)\end{array}$ & 4 \\
\hline 5 & Roni Permana Saputra S.T. & 4 & $\begin{array}{c}\text { Perancangan Mesin } \\
(15.01)\end{array}$ & 5 \\
\hline 6 & Vita Susanti, S.Kom & 3 & $\begin{array}{c}\text { Teknik Sistem } \\
\text { Informasi (14.04) }\end{array}$ & 6 \\
\hline 7 & Arif Santoso, S.T. & 3 & $\begin{array}{c}\text { Perancangan Mesin } \\
(15.01)\end{array}$ & 6 \\
\hline 8 & Tinton Dwi Atmaja, M.T. & 2 & $\begin{array}{c}\text { Tenaga Listrik } \\
(16.01)\end{array}$ & 7 \\
\hline 9 & Edwar Yazid, S.T. & 2 & $\begin{array}{c}\text { Perancangan Mesin } \\
(15.01)\end{array}$ & 7 \\
\hline 10 & Rizqi Andry Ardiansyah, S.ST & 2 & $\begin{array}{c}\text { Elektronika } \\
(16.02)\end{array}$ & 7 \\
\hline
\end{tabular}


Tabel 11. Artikel metrik jurnal MEV tahun 2010-2016

\begin{tabular}{|c|c|c|c|c|}
\hline No. & $\begin{array}{l}\text { Volume/nomor/ } \\
\text { tahun }\end{array}$ & $\begin{array}{l}\text { Nama orang dan } \\
\text { Kolaborasi }\end{array}$ & Judul & $\begin{array}{l}\text { Artikel } \\
\text { Metrik }\end{array}$ \\
\hline 1 & Vol. 7(1), 2016 & $\begin{array}{c}\text { Noor Cholis } \\
\text { Basjaruddin, } \\
\text { Kuspriyanto } \\
\text { Kuspriyanto, Suhendar } \\
\text { Suhendar, Didin } \\
\text { Saefudin, Virna Apriani } \\
\text { Azis }\end{array}$ & $\begin{array}{l}\text { Hardware simulation of automatic } \\
\text { braking system based on fuzzy logic } \\
\text { control }\end{array}$ & 412 \\
\hline 2 & Vol.2(1), 2011 & Irhan Febijanto & $\begin{array}{c}\text { Kajian Teknis \& Keekonomian } \\
\text { Pembangkit Listrik Tenaga Biomasa } \\
\text { Sawit; Kasus: Di Pabrik Kelapa } \\
\text { Sawit Pinang Tinggi, Sei Bahar, } \\
\text { Jambi }\end{array}$ & 401 \\
\hline 3 & Vol.1(1), 2010 & Ridwan Arief Subekti & $\begin{array}{l}\text { Survey Potensi Pembangkit Listrik } \\
\text { Tenaga Mikro Hidro di Kuta Malaka } \\
\text { Kabupaten Aceh Besar Propinsi } \\
\text { Nanggroe Aceh Darussalam }\end{array}$ & 397 \\
\hline 4 & Vol. 7(1), 2016 & $\begin{array}{c}\text { Kadek Heri Sanjaya, } \\
\text { Soomin Lee, Tetsuo } \\
\text { Katsuura }\end{array}$ & $\begin{array}{l}\text { Review on the application of } \\
\text { physiological and biomechanical } \\
\text { measurement methods in driving } \\
\text { fatigue detection }\end{array}$ & 337 \\
\hline 5 & Vol.1(1), 2010 & $\begin{array}{l}\text { Pudji Irasari, Aditya } \\
\text { Sukma Nugraha, } \\
\text { Muhammad Kasim }\end{array}$ & $\begin{array}{l}\text { Analisis Getaran pada Generator } \\
\text { Magnet Permanen 1kW Hasil } \\
\text { Rancang Bangun Pusat Penelitian } \\
\text { Tenaga Listrik dan Mekatronik }\end{array}$ & 262 \\
\hline 6 & Vol. 7(1), 2016 & $\begin{array}{l}\text { Maher A.R. Sadiq Al- } \\
\text { Baghdadi }\end{array}$ & $\begin{array}{c}\text { A CFD model for analysis of } \\
\text { performance, water and thermal } \\
\text { distribution, and mechanical related } \\
\text { failure in PEM fuel cells }\end{array}$ & 251 \\
\hline 7 & Vol.2(2), 2011 & $\begin{array}{l}\text { Dalmasius Ganjar } \\
\text { Subagio, Tinton Dwi } \\
\text { Atmaja }\end{array}$ & $\begin{array}{l}\text { The Use of Open Source Software } \\
\text { for Open Architecture System on } \\
\text { CNC Milling Machine }\end{array}$ & 238 \\
\hline 8 & Vol. 7(1), 2016 & $\begin{array}{l}\text { Liana Ellen Taylor, } \\
\text { Midriem Mirdanies, } \\
\text { Roni Permana Saputra }\end{array}$ & $\begin{array}{l}\text { Optimized object tracking technique } \\
\text { using Kalman filter }\end{array}$ & 230 \\
\hline 9 & Vol.2(1), 2011 & $\begin{array}{l}\text { Midriem Mirdanies, } \\
\text { Rizqi Andry } \\
\text { Ardiansyah, Hendri } \\
\text { Maja Saputra, Aditya } \\
\text { Sukma Nugraha, Estiko } \\
\text { Rijanto, Adi Santoso }\end{array}$ & $\begin{array}{c}\text { Rancang Bangun Sistem Kontrol } \\
\text { Mekanisme Pelacakan Matahari } \\
\text { Beserta Fasilitas Telekontrol Hemat } \\
\text { Energi }\end{array}$ & 225 \\
\hline 10 & Vol.6(2), 2015 & $\begin{array}{l}\text { Ali Sadiyoko, Bambang } \\
\text { Riyanto Trilaksono, } \\
\text { Kusprasapta Mutijarsa, } \\
\text { Widyawardana } \\
\text { Adiprawita } \\
\end{array}$ & $\begin{array}{l}\text { Obstacle Avoidance Method for a } \\
\text { Group of Humanoids Inspired by } \\
\text { Social Force Model }\end{array}$ & 213 \\
\hline
\end{tabular}




\section{DAFTAR GRAFIK}

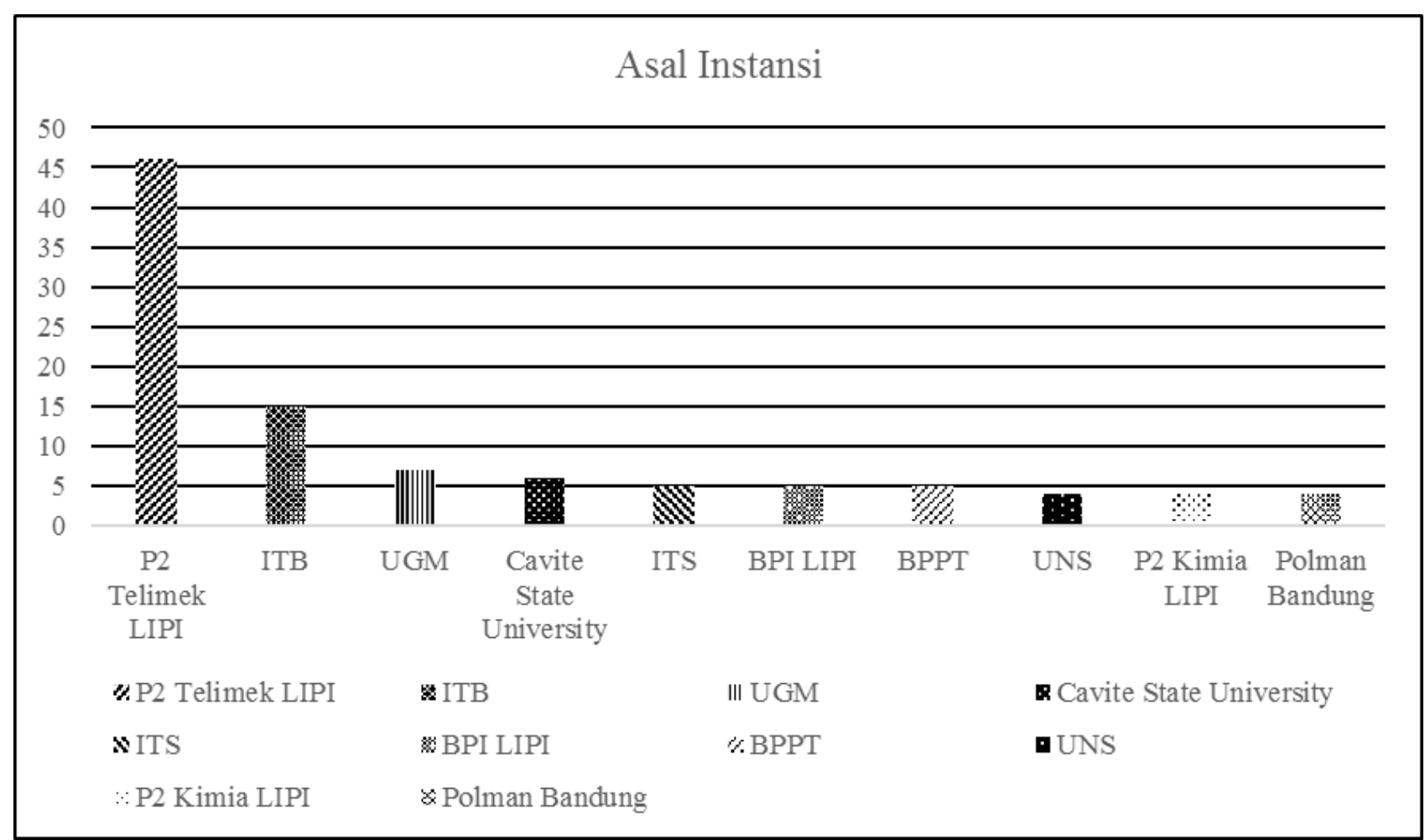

Grafik 1. Asal instansi penulis jurnal MEV 